\title{
PENGALAMAN KERJA, SKEPTISME PROFESIONAL, TEKANAN WAKTU DAN PENDETEKSI FRAUD (STUDI PADA BPKP JAWA TENGAH)
}

\author{
Joshua Mitchel Soenanto ${ }^{1}$, David A. A. Pesudo ${ }^{2}$ \\ ${ }^{1,2}$ Program Studi Akutansi Fakultas Ekonomika dan Bisnis \\ Universitas Kristen Satya Wacana, Salatiga
}

e-mail: joshuamitchelsoenanto@gmail.com, david.pesudo@uksw.edu

\begin{abstract}
Abstrak
Penelitian ini bertujuan untuk mengetahui pengaruh pengalaman kerja, skeptisme profesional, dan tekanan waktu terhadap pendeteksi fraud pada BPKP (Badan Pengawasan Kuangan dan Pembangunan) Jawa Tengah. Penelitian ini menggunakan pendekatan deskriptif kuantitatif, dimana kuesioner digunakan sebagai instrumen penelitian. Teknik sampel yang digunakan yaitu saturated sampling sehingga diperoleh 45 sampel auditor internal BPKP sebagai responden dalam penelitian ini. Teknik analisis yang digunakan analisis linear berganda. Analisis ini meliputi: uji validitas dan realibilitas, uji asumsi klasik, uji hipotesis. Hasil dari penelitian ini menunjukkan bahwa pengalaman kerja dan skeptisme profesional memiliki pengaruh positif yang signifikan terhadap pendeteksi fraud tetapi untuk variabel tekanan waktu memiliki pengaruh negatif yang signifikan terhadap pendeteksi fraud pada BPKP Jawa Tengah.
\end{abstract}

Kata kunci : Pengalaman Kerja, Skeptisme Profesional, Tekanan Waktu, Pendeteksi Fraud

\begin{abstract}
This purpose of the research is to determine the effect of work experience, professional skeptism, and time pressure on fraud detection in BPKP (Badan Pengawasan Keuangan dan Pembangunan), Central Java. This research is a quantitative descriptive study where the questionares is used as a research instrument. Saturated sampling technique is used in order to obtain 45 samples of internal auditor as respondents. Multiple Linear Analysis is used as analysis technique, includes : validity test, reability test, classic assumption test, hypothesis test. The result of this study indicate that work experience and professional skeptism has a significant positive effect on fraud detection, but time pressure has a negative significant effect on fraud detection in BPKP (Badan Pengawasan Keuangan dan Pembangunan), Central Java.
\end{abstract}

Keywords : Work experience, Professional Skeptism, Time Pressure, Fraud Detection 


\section{PENDAHULUAN}

Indonesia sempat mengalami krisis ekonomi pada tahun 1998, dimana peristiwa itu dituding sebagai penyebab maraknya praktik-praktik fraud dalam pemerintahan yang kita kenal dengan istilah "white collar crime"(Kristina, 2018). Menurut Lestari (2016) White collar crime atau kejahatan kerah putih merupakan kejahatan yang identik dilakukan oleh seseorang atau sekelompok orang yang memiliki jabatan maupun kekuasaan. Butar \& Perdana (2017) dalam penelitiannya mengatakan bahwa, saat ini Indonesia menempati peringkat ke 88 dari 168 negara dalam Corruption Perceptions Index (CPI) pada tahun 2015. Hal ini menunjukkan tingginya angka korupsi di sektor publik Indonesia. Pada tahun 2017 terdapat kasus yang terjadi di pemerintahan yang melibatkan auditor internal secara langsung dan merugikan negara sebesar Rp. 2,314 Triliun (Putra, 2017). Polda Jateng sudah menangani setidaknya 32 kasus dugaan korupsi yang melibatkan para pejabat di Jateng, dan dari 32 kasus tersebut baru 7 perkara yang berkasnya sudah lengkap, delapan kasus masih perlu penyempurnaan, 3 kasus telah di limpahkan ke instansi lain (KPK dan Kejaksaan), dan 14 kasus lainnya masih dalam proses penyidikan (www.bpkp.go.id, 2011). Untuk kasus tersebut BPKP berperan dalam mengawasi dan mencari berapa nilai kerugian yang dialami oleh negara, dimana BPKP memerlukan waktu setidaknya tiga bulan untuk mencari nilai kerugian tersebut. Adanya fenomenafenomena yang terkait dengan fraud tersebut membuat kepercayaan publik terhadap kemampuan auditor internal menurun, sehingga sangat diperlukan bagi auditor internal untuk meningkatkan kemampuannya dalam pendeteksian fraud, dengan meningkatnya kemampuan auditor internal dalam melakukan pendeteksian fraud maka auditor internal pemerintah dapat mengotimalkan perannya dalam melakukan pendeteksian fraud (Daraori, 2017).

Auditor internal merupakan suatu kegiatan yang independen didalam suatu organisasi yang tugasnya mengetes dan melakukan evaluasi terhadap kegiatan atau program yang dijalankan (Tugiman, 2019). Auditor internal mempunyai kemampuan pendeteksi fraud yang berbeda-beda karena dipengaruhi oleh beberapa faktor, diantaranya pengalaman kerja, skeptisisme profesional dan tekanan waktu. Menurut Suraida dalam Ningtyas, Delamat, \& Yuniartie (2019), seorang auditor internal dapat berhasil dalam pendeteksian fraud karena dipengaruhi oleh pengalaman. Auditor internal yang sudah memiliki banyak pengalaman akan dengan mudah melakukan pendeteksian fraud karena sudah mengetahui celah-celah yang rawan akan penyalahgunaan. Pengalaman auditor internal dianggap menjadi faktor pendukung dalam mengindikasi kinerja auditor internal karena semakin banyak pengalaman yang dimiliki, maka akan semakin baik hasil audit yang dihasilkan dinyatakan dalam penelitian (Ningtyas et al., 2019).

Selain pengalaman ada juga faktorfaktor lain yang mempengaruhi keberhasilan auditor internal dalam pendeteksian fraud, antara lain adalah skeptisisme profesional dan tekanan waktu. Auditor internal yang bersikap tidak skeptis cenderung tidak mampu melakukan pendeteksian fraud karena bukti yang mengarah pada fraud tidak di gali lebih dalam dan auditor internal percaya begitu saja terhadap asersi yang diberikan. Anggriawan (2014) dalam penelitiannya menyatakan bahwa skeptisisme profesional mendukung kemampuan auditor internal dalam pendeteksian fraud. Semakin tinggi skeptisisme seorang auditor internal maka kemampuan pendeteksian fraud juga semakin baik. Menurut Ningtyas et al., (2019) pengalaman dan skeptisisme profesional berpengaruh terhadap pendeteksian fraud namun ada satu faktor lain yang mempengaruhi yaitu Keahlian.

Tekanan waktu merupakan batasan waktu yang diberikan untuk auditor internal dalam melaksanakan tugasnya dimana desakan waktu mengharuskan auditor untuk berpikir secara kritis dan selalu menanyakan banyak hal agar tugasnya selesai sesuai dengan susunan waktu yang telah diberikan. Menurut Koroy dalam Putra, Andreas, \& Hardi (2016) tekanan waktu merupakan salah satu faktor bawaan yang harus dihadapi oleh auditor internal, dengan adanya batasan waktu yang diberikan maka auditor internal diharuskan bekerja secara cepat. Penelitian terdahulu telah dilakukan oleh Putra et al., (2016) yang menyatakan bahwa tekanan waktu tidak mendukung auditor internal dalam pendeteksian fraud karena disebabkan oleh kecilnya batasan waktu yang diberikan untuk auditor internal dalam melaksanakan tugasnya.

Berdasarkan latar belakang yang telah diungkapkan di atas persoalan masalah dari penelitian ini adalah, 1) Apakah pengalaman kerja dapat berpengaruh terhadap pendeteksian fraud? 2) Apakah skeptisme profesional dapat berpengaruh terhadap pendeteksian fraud? 3) Apakah tekanan waktu dapat berpengaruh terhadap pendeteksian fraud?. Jika dilihat dari ketiga persoalan diatas 
maka, studi ini bertujuan untuk mendeskripsikan bagaimana pengalaman kerja, skeptisisme professional, dan tekanan waktu mempengaruhi auditor internal dalam pendeteksian fraud. Penelitian ini diharapkan dapat bermanfaat dan dapat dijadikan landasan untuk pengembangan pembelajaran. Studi ini juga diharapkan dapat bermanfaat bagi auditor internal sebagai cerminan bahwa pengalaman kerja, sikap skeptis dan tekanan waktu dapat membantu auditor internal, bagi peneliti selanjutnya penelitian ini bisa dijadikan sebagai referensi dan menambah wawasan tentang variabel dan objek yang serupa. Selain itu, studi ini bisa digunakan untuk memfasilitasi mahasiswa dalam proses belajar dan bagi para pembaca dengan adanya penelitian ini dapat menambah wawasan mengenai bagaimana pengaruh pengalaman kerja, skeptisisme professional, dan tekanan waktu dalam pendeteksian fraud.

Menurut Purba (2015) pengalaman yang dimiliki oleh auditor internal untuk pendeteksian fraud sangat penting karena fraud dapat di deteksi dengan mempercayakan tugas investigasi ke orang yang sudah memiliki pelatihan dan banyak pengalaman di bidang auditor internal. Jika tugas investigasi tersebut di berikan ke orang yang tidak memiliki pelatihan dan pengalaman maka dapat membahayakan tugas dari investigasi itu sendiri. Auditor internal juga harus menguasai elemen penting untuk melakukan pendeteksian fraud, salah satunya dengan cara bersikap skeptis atau bersikap untuk tidak mempercayai pernyataan yang diberikan secara langsung (Tuanakotta, 2011). Menurut Supriyanto (2014) fraud dapat dideteksi dengan bersikap skeptis sehingga sikap tersebut dapat mengarahkan auditor internal untuk menanyakan setiap bukti audit yang diberikan dan mencari gejala-gejala yang mengisyaratkan adanya fraud.

$$
\text { Pengalaman kerja merupakan }
$$

komponen penting bagi auditor internal, karena dengan memiliki pengalaman kerja yang cukup auditor internal dapat dipercaya untuk mengerjakan investigasi dalam pendeteksian fraud dan paling tidak sudah memiliki 2 tahun pengalaman kerja (Albrecht et al., 2006). Arsendy Anugerah, \& Diyanto (2017) auditor internal yang tidak memiliki pengalaman kerja akan sulit untuk melakukan pendeteksian fraud tetapi jika pengalaman kerjanya tinggi maka auditor cenderung memiliki kemampuan pendeteksian fraud yang tinggi. Seperti yang di katakan oleh Aulia (2013) auditor internal yang sudah lama bekerja akan memiliki suatu cara untuk melakukan pendeteksian fraud yang akan terjadi, dan juga auditor internal yang memiliki jam terbang tinggi akan lebih teliti untuk melakukan pendeteksian fraud. Hal ini menunjukan bahwa semakin auditor berpengalaman maka semakin dalam juga auditor internal memiliki pengetahuan dalam pendeteksian fraud.

Kartikasari, Irianto, \& Prihatiningtias (2017) menyatakan bahwa sikap skeptisme profesional dalam pendeteksian fraud akan semakin tinggi jika ada dorongan motivasi dari diri sendiri, sedangkan motivasi diri ini bergantung pada nilai masing-masing individu sehingga mereka dapat menyelesaikan apa yang menjadi tanggung jawabnya. Jika dalam penugasannya auditor internal selalu bersikap skeptis maka semakin meningkat juga kemampuan auditor internal untuk melakukan pendeteksian fraud (Prasetyo, 2015). Bersikap skeptis merupakan suatu hal yang penting bagi auditor internal untuk melakukan proses, dimana auditor internal harus selalu menanyakan dan mengevaluasi secara kritis terhadap bukti audit yang diberikan. Apabila auditor internal dengan mudahnya percaya pada bukti audit yang diberikan tanpa mengkritisi bukti tersebut maka tingkat fraud akan semakin meningkat (Trinanda, 2016).

Salah satu ciri lingkungan yang sering dihadapi oleh auditor internal adalah tekanan waktu. Adanya tekanan waktu yang ditetapkan membuat auditor internal memiliki masa sibuk yang dituntut untuk bekerja secara cepat. Koroy (2010) mengatakan bahwa auditor internal yang diberi batasan waktu dalam melakukan pendeteksian fraud akan berpeluang gagal dalam mengumpulkan buktibukti audit secara maksimal. Tekanan waktu mempengaruhi kinerja seseorang dalam melakukan pendeteksian fraud karena dalam melakukan praktiknya auditor perlu waktu untuk merencanakannya dengan baik supaya hasil pengungkapan yang disampaikan dapat maksimal (Umri et al., 2015). Tugas yang diberikan ke auditor internal harus diselesaikan dengan jangka waktu tertentu membuat auditor internal harus menyesuaikan antara waktu atau tugas yang harus diselesaikan. Jika waktu yang telah diestimasikan tidak sesuai dengan waktu yang dibutuhkan, maka auditor internal akan cenderung menjadi kurang teliti dan hanya beberapa tugas saja yang diprioritaskan agar dapat memenuhi waktu yang sudah diestimasikan (Hafizhah \& Abdurahim, 2019).

Pengalaman merupakan salah satu faktor penting bagi auditor internal dalam mendeteksi fraud semakin banyak pengalaman yang diperoleh auditor internal semakin cepat juga auditor internal melakukan 
pendeteksian fraud dibandingkan dengan auditor internal dengan pengalaman audit yang rendah (Ranu \& Merawati, 2017). Menurut Anggriawan (2014) pengalaman kerja auditor internal berpengaruh signifikan terhadap pendeteksian fraud, karna semakin lama auditor bekerja dan banyak tugas yang ditangani maka dapat dikatakan bahwa auditor tersebut semakin berpengalaman. Auditor internal yang berpengalaman akan memiliki lebih banyak pengetahuan tentang gejalagejala terjadinya fraud, sehingga dengan pengetahuan tersebut auditor internal dapat menilai bukti-bukti yang relevan yang dapat membantu menyelesaikan tugasnya (Yusrianti, 2015). Hal ini juga didukung dalam penelitian Nasution (2012) yang mengatakan bahwa pengalaman kerja memiliki pengaruh positif terhadap pendeteksian fraud, auditor internal yang semakin berpengalaman maka akan lebih paham terkait pendektesian fraud. Berdasarkan uraian diatas, maka dapat dirumuskan hipotesis penelitian yang pertama sebagai berikut.

Sikap skeptisme profesional merupakan sikap dimana auditor internal akan selalu berskiap kritis dan selalu mempertanyakan pernyataan yang diberikan. Oleh karena itu, skeptisme profesional merupakan sikap yang harus dimiliki oleh auditor internal. Sikap tersebut tujuannya untuk menjaga agar auditor internal tidak langsung percaya dengan asersi yang ada, sehingga dapat digunakan dalam pendeteksian fraud. Biksa \& Wiratmaja (2017) mengatakan bahwa Auditor internal yang memiliki sikap skeptisme tinggi akan selalu mengembangkan informasi-informasi yang telah didapatkan agar menambah bukti dalam melakukan pendeteksian fraud .Ranu \& Merawati (2017) dengan tingginya sikap skeptis yang dimiliki auditor internal maka auditor internal dapat melakukan pendeteksian fraud secara maksimal. Menurut Hilmi (2011) skeptisme profesional berpengaruh signifikan dalam pendeteksian fraud, dengan selalu bersikap kritis dan mengevaluasi asersi-asersi yang diberikan maka fraud dapat dideteksi sehingga fraud tersebut tidak tejadi. Penelitian ini sejalan dengan penelitian Hariyani, \& Ramadhany (2015) yang mengatakan bahwa skeptisme profesional berpengaruh signifikan terhadap pendeteksian fraud. Hasil tersebut membuktikan bahwa semakin meningkatnya skeptisme profesional auditor internal maka akan semakin baik pula kemampuan auditor internal dalam pendeteksian fraud. Berdasarkan uraian diatas, maka dapat dirumuskan hipotesis penelitian yang kedua sebagai berikut.
Tekanan waktu merupakan kondisi dimana seorang auditor internal dituntut untuk menyelesaikan tugasnya dengan jangka waktu yang telah diberikan, batasan waktu yang singkat maka akan mengakibatkan pendeteksian fraud menjadi tidak maksimal dan membuat auditor internal dalam mengumpulkan informasi menjadi kurang maksimal karena auditor internal tidak akan mampu bersikap kritis dengan sedikitnya waktu yang diberikan.

Sedikit waktu yang diberikan membuat auditor internal tidak nyaman karena bukti yang dikumpulkan tidak sesuai dengan harapan auditor internal akibat keterbatasan waktu (Dandi et al., 2017). Menurut Putra et al., (2016) tekanan waktu yang diberikan akan membuat auditor internal merasa memiliki kewajiban yang harus diselesaikan, karena adanya batasan waktu yang diberikan akan membuat auditor internal didesak atau dituntut agar dapat menyelesaikan pekerjaannya sesuai dengan waktu yang telah ditentukan. Auditor internal yang ditekan oleh waktu akan merasa tidak nyaman karna merasa informasi yang dikumpulkan hanya beberapa saja dan tidak dapat dimaksimalkan dengan baik, sehingga dalam pendeteksian fraud hasil yang diberikan auditor internal nantinya tidak akan bisa semaksimal mungkin (Pratiwi, 2017). Dari hasil penelitian diatas dapat dipahami bahwa, jika auditor internal yang memiliki batasan waktu dalam penugasannya, maka hasil dari pendeteksian fraud akan menjadi tidak maksimal karena tertekan oleh waktu. Penelitian ini sejalan dengan penelitian Sahidin (2018) yang mengatakan bahwa tekanan waktu berpengaruh negatif terhadap pendeteksian fraud. Berdasarkan uraian diatas, maka dapat dirumuskan hipotesis penelitian yang ketiga dan keempat sebagai berikut.

\section{METODE}

Pendekatan dalam penelitian ini adalah pendekatan kuantitatif, yang digunakan untuk melihat pengaruh dan menguji hubungan antar variabel. Penelitian ini menggunakan pengalaman kerja, skeptisme professional dan tekanan wktu sebagai variabel independen lalu pendeteksi fraud sebagai variabel dependen.

Populasi yang digunakan dalam penelitian ini adalah seluruh auditor internal yang ada di BPKP Jawa Tengah. Pemilihan sampel didalam penelitian ini menggunakan saturated sampling, karena mengambil seluruh populasi yaitu seluruh auditor internal di BPKP Jawa Tengah.

Penelitian ini menggunakan kuesioner yang berisikan pernyataan tentang variabel 
terkait. Sebagian besar indikator variabel diambil dari penelitian terdahulu lalu dikembangkan dengan menggunakan 5 poin skala ordinal. 1 (satu) untuk Sangat Tidak Setuju (STS) hingga 5 (lima) untuk Sangat Setuju (SS).

Uji Reabilitas dan Uji Validitas bertujuan untuk menguji valid atau tidaknya sebuah data. Data dinyatakan valid apabila nilai r-hitung $>r$ tabel pada signifikansi 0,05 (5\%), sedangkan Uji Reabilitas dikatakan reliabel atau handal apabila responden mengisi kuesioner secara konsisten.

\section{HASIL DAN PEMBAHASAN}

Data Penelitian ini dilakukan dengan menyebar kuesioner di Badan Pengawasan Keuangan dan Pembangunan (BPKP) Jawa Tengah yang ditujukan kepada Auditor BPKP sebanyak 50 orang, dimana ada 2 kuesioner tidak kembali dan 3 kuesioner tidak diisi secara lengkap sehingga peneliti hanya menggunakan 45 kuesioner.

Hasil dari SPSS menunjukan perhitungan 45 sampel yang telah digunakan dalam penelitian ini. Dimana pada variabel pengalaman kerja terdapat nilai terendah sebesar 30 dan nilai tertinggi sebesar 45 dengan nilai rata-rata 39,27 yang memiliki standar deviasi sebesar 3,215. Lalu pada variabel skeptisme profesional memiliki nilai minimum sebesar 32 dengan nilai maksimum 50 dan nilai rata-rata sebesar 43,47 yang memiliki standar deviasi 3,817. Pada variabel Tekanan waktu nilai minimumnya sebesar 20 dan nilai maksimumnya sebesar 30 dengan nilai rata-rata 24,64 yang memiliki standar deviasi sebesar 3,054. Dan di variabel pendeteksi fraud nilai minimumnya sebesar 36 dan nilai maksimumnya sebesar 50 dengan rata-rata 44,16 yang memiliki standar deviasi sebesar 3,384.
Uji Validitas bertujuan untuk menguji valid atau tidaknya sebuah data dengan membandingkan data $r$-hitung dengan $r$-tabel.

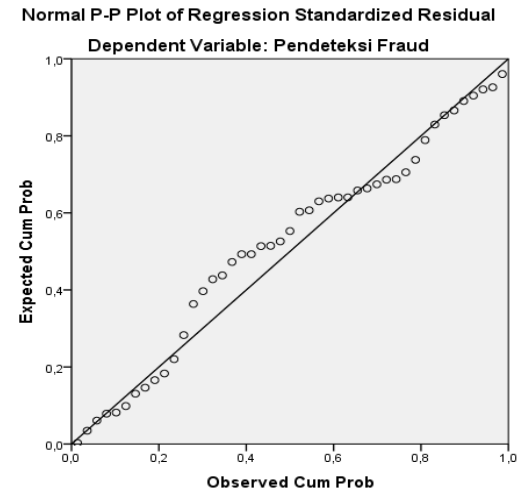

Dapat diakatakan valid apabila nilai r-hitung > r-tabel. Variabel pengalaman kerja, skeptisme profesional, tekanan waktu dan pendeteksi fraud memiliki $r$-hitung yang lebih besar dari pada r-tabel dengan menggunakan nilai signifikansi sebesar 0,05 . Dengan demikian pertanyaan-pertanyaan diatas dapat dikatakan valid.

Uji reliabilitas digunakan untuk mengetahui apakah instrumen-instrumen setiap variabel yang ada pada penelitian ini dapat diandalkan. Penelitian ini menggunakan metode spearman brown untuk menguji metode reabilitas. Variabel pada penelitian ini dapat diandalkan apabila nilai reliabilitas atau lebih besar dibandingkan nilai r-tabel.

Uji normalitas digunakan untuk mengetahui residual dalam penelitian ini berdistribusi normal atau tidak. Pada penelitian ini, metode yang digunakan untuk menguji normalitas adalah metode KolmogorovSmirnov dan Normal P-P Plot of Regression Standardized Residual.

Gambar 1. Grafik Uji Normalitas

Tabel 1. Uji Normalitas Kolmogorov-smrinov

\begin{tabular}{llr}
\hline & & Unstandardized Residual \\
\hline $\mathrm{N}$ & Mean & 45 \\
Normal Parameters & 0 \\
& Std. Deviation & 2,62310023 \\
Most Extreme Differences & Absolute & 0,104 \\
& Positive & 0,52 \\
Test Statistic & Negative & $-0,104$ \\
Asymp. Sig. (2-tailed) & & 0,104 \\
\hline
\end{tabular}

Berdasarkan grafik 1 dan Tabel 1 perhitungan diatas, dapat dilihat bahwa titik- titik pada grafik mengikuti garis keatas maka data tersebut berdistribusi normal. Lalu pada 
tabel uji normalitas dengan kolmogorovsmirnov Asymp. Sig. (2-tailed) menunjukan nilai 0,200 dan lebih besar dari 0,05 , sehingga data tersebut berdisribusi normal.

Uji multikolinearitas digunakan untuk mengetahui apakah ada hubungan korelasi antar hubungan independen. Metode yang digunakan untuk menguji multikolinearitas adalah dengan melihat tolerance dan VIF pada tiap variabel yang terdapat di tabel koefisien. Penelitian ini dikatakan tidak multikolinearitas apabila nilai tolerance $>0,1$ dan nilai VIF $<10$.

Tabel 2. Hasil Uji Multikolinearitas

\begin{tabular}{llrr}
\hline \multirow{2}{*}{ Model } & & \multicolumn{2}{c}{ Collinearity Statistics } \\
\cline { 3 - 4 } & & \multicolumn{2}{c}{ Tolerance } \\
& (Constant) & 0,955 & VIF \\
& Pengalaman Kerja & 0,998 & 1,047 \\
& Skeptisme Profesional & 0,984 & 1,002 \\
& Tekanan Waktu & 1,016 \\
\hline
\end{tabular}

Dari tabel di atas, dapat dilihat bahwa tidak terjadi multikolinearitas antara variabel independen. Dapat dilihat bahwa tiap variabel memiliki nilai tolerance yang lebih besar dari 0,1 dan nilai VIF yang lebih kecil dari 10 .

Uji Heteroskedastisitas digunakan untuk mengetahui apakah didalam suatu model terdapat persamaan atau perbedaan varian dari residual atau tidak. Metode yang digunakan dalam penelitian ini adalah metode scatterplot, jika tidak ada pola tertentu, maka mengindikasikan tidak terjadinya heteroskedastisitas

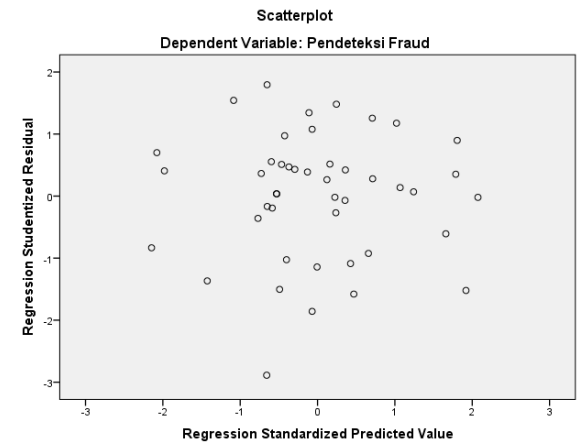

Gambar 1 Uji Heteroskedastisitas
Dari gambar di atas, dapat dilihat bahwa tidak terdapat heteroskedastisitas pada penelitian ini. Hal tersebut ditunjukan oleh titiktitik yang tidak membentuk suatu pola tertentu serta titik-titik tersebut tersebar di atas dan di bawah angka 0 pada sumbu $X$ dan $Y$.

Autokorelasi merupakan uji yang digunakan untuk melihat apakah terdapat kesalahan atau penyimpangan pada periode $t$ dengan kesalahan periode t-1 (sebelumnya). Untuk mengetahui ada atau tidaknya autokorelasi pada penelitian ini menggunakan runs test dimana nilai Asymp. Sig. (2-tailed) pada uji ini harus $>0,05$ agar tidak terdapat gejala autokorelasi.

Tabel 3. Uji Autokorelasi

\begin{tabular}{lc}
\hline & Runs Test \\
& Unstandardized Residual \\
\hline Test Value ${ }^{a}$ &,- 10105 \\
Cases $<$ Test Value & 22 \\
Cases $>=$ Test Value & 23 \\
Total Cases & 45 \\
\hline Number of Runs & 27 \\
$Z$ &, 909 \\
Asymp. Sig. (2-tailed) &, 364 \\
\hline
\end{tabular}


Hasil dari uji diatas menunjukan bahwa Asymp. Sig. (2-tailed) pada penelitian ini sebesar 0,364 > dari 0,05 dan dapat dikatakan bahwa tidak terjadi autokorelasi pada penelitian ini.
Uji t digunakan untuk melihat pengaruh antar variabel bebas terhadap variabel terikat secar parsial. Hasil dari pengaruh tersebut dapat dilihat dari taraf signifikansinya, ketika taraf signifikansinya berada dibawah 0,05 maka pengaruh tersebut signifikan.

Tabel 4. Uji t

\begin{tabular}{lllll}
\hline Model & & Beta & $t$ & Sig. \\
\hline 1 & (Constant) & & 3,380 & 0,002 \\
& Pengalaman Kerja & 0,320 & 2,595 & 0,013 \\
& Skeptisme Profesional & 0,287 & 2,211 & 0,033 \\
& Tekanan waktu & $-0,326$ & $-2,489$ & 0,017 \\
\hline
\end{tabular}

Pada tabel diatas dapat dilihat bagaimana pengaruh antara hubungan pengalaman kerja, skeptisme profesional, dan tekanan waktu dengan pendeteksi fraud. Dari data tersebut dapat dilihat pada tabel B dan tabel $t$ bahwa pengalaman kerja memiliki pengaruh positif terhadap pendeteksian fraud, pengaruh positif ini juga memiliki signifikansi sebesar 0,013 yang berarti berada dibawah 0,05 dan memiliki beta sebesar 0,320. Berarti dapat dikatakan bahwa niat pengalaman kerja memiliki pengaruh positif yang signifikan terhadap pendeteksi fraud.

Untuk pengaruh skeptisme profesional terhadap pendeteksi fraud, dapat dilihat dari tabel $B$ dan tabel $t$ bahwa skeptisme profesional memiliki pengaruh positif terhadap pendeteksi fraud dengan nilai signifikansi sebesar 0,033, yang berarti sangat signifikan (berada dibawah 0,05) dan memiliki beta sebesar 0,287, maka dapat dikatakan bahwa skeptisme profesional memiliki pengaruh positif yang signifikan terhadap pendeteksi fraud.

Pengaruh Tekanan waktu terhadap pendeteksian fraud dapat dilihat dari tabel $\mathrm{B}$ dan $t$ dimana tekanan waktu memiliki pengaruh negatif terhadap pendeteksi fraud dengan tingkat signifikansi 0,017 dan memiliki beta sebesar -0,326, maka dapat dikatakan bahwa tekanan waku memiliki pengaruh negatif terhadap pendeteksi fraud.

Uji Koefisien Determinasi atau Uji $\mathrm{R}^{2}$ digunakan untuk menguji seberapa besar pengaruh variabel bebas terhadap varibel terikat yang dapat diprediksi, serta melihat besarnya pengaruh variabel bebas lainnya yang tidak terdapat pada penelitian ini terhadap varibel terikat.

Tabel 5. Uji koefisien Determinasi (R2)

\begin{tabular}{crrrrr}
\hline Model & $R$ & $R$ Square & Adjusted R Square & Std. Error of the Estimate & \\
\hline 1 &, $555^{\text {a }}$ & 0,309 & 0,258 & 2,915 \\
\hline
\end{tabular}

Berdasarkan hasil diatas $R$ Square menunjukan 0,309 , sehingga dapat dikatakan bahwa terdapat pengaruh variabel pengalaman kerja, skeptisme profesional, dan tekanan waktu sebesar 30,9\% terhadap pendeteksi fraud, sedangkan tersisa 69,1\% pengaruh yang diakibatkan oleh variabel lain yang tidak dijelaskan didalam penelitian ini.

Hasil dari pengaruh pengalaman kerja terhadap pendeteksi fraud mendukung hipotesis pertama yang mengatakan "Pengalaman kerja berpengaruh positif terhadap pendeteksi fraud". Hasil penelitian terebut konsisten dengan hasil penelitian yang dilakukan Anggriawan (2014) yang menyatakan bahwa pengalaman audit berpengaruh positif terhadap kemampuan pendeteksian kecurangan.
Frederick (1990) dalam Nasution (2014) mengatakan bahwa auditor internal yang berpengalaman tidak hanya mampu untuk menemukan fraud tapi auditor internal yang sudah berpengalaman juga harus mampu memberi penjelasan yang lebih akurat dari auditor internal yang kurang berpengalaman.

Auditor internal yang sudah lama bekerja dan memiliki beberapa perusahaan yang sudah ditangani, maka auditor internal akan lebih berpengalaman dalam mendeteksi fraud, dan dengan pengalaman tersebut dapat membuat auditor internal akan meningkatkan kesadaran auditor internal jika terjadi kekeliruan. Auditor internal yang berpengalaman akan lebih paham penyebab apa saja yang membuat terjadinya fraud, apakah murni dari kesalahan yang disengaja atau kesalahan yang tidak disengaja oleh 
manusia atau alat. Hal ini sejalan dengan penelitian yang dilakukan oleh (Sahidin, 2018).

Hasil dari pengaruh pengalaman kerja terhadap pendeteksi fraud mendukung hipotesis yang kedua yang mengatakan "Skeptisme Profesional berpengaruh positif terhadap pendeteksi fraud". Skeptisme profesional dapat membantu auditor internal dalam melakukan pendeteksi fraud dengan melakukan evaluasi kritis terhadap bukti auditnya dengan tidak langsung percaya dengan apa yang telah diungkapkan.

Auditor internal yang memiliki sikap skeptisme yang tinggi akan meningkatkan kemampuan auditor internal dalam mendeteksi fraud. Semakin auditor internal sering bertanya atau bersikap skeptis maka auditor internal akan lebih berhati-hati dalam mengambil keputusan yang akan diambil dengan cara mencari bukti-bukti yang akurat dan bukti tersebut akan menjadi informasi auditor internal untuk mendukung kesimpulannya. Ini menunjukan bahwa semakin tinggi sikap skeptisme seorang auditor internal maka tingkat pendeteksi fraud akan meningkat. Hal ini sejalan dengan penelitian yang telah dilakukan oleh (Simanjuntak et al., 2015).

Hasil dari pengaruh tekanan waktu terhadap pendeteksi fraud mendukung hipotesis yang ketiga yang mengatakan "Tekanan Waktu berpengaruh negatif terhadap pendeteksi fraud". Semakin auditor internal tertekan oleh waktu maka kesempatan auditor internal dalam melakukan pendeteksian fraud akan menurun, sehingga tekanan waktu membuat auditor internal tertekan karena bukti-bukti audit yang dikumpulkan tidak maksimal dan cenderung terlewatkan.

Hal ini sejalan dengan penelitian yang dilakukan Dandi \& Safitri (2017) bahwa tekanan waktu berpengaruh negatif terhadap pendeteksi fraud. Sedikit waktu yang diberikan untuk auditor internal akan membuat auditor internal tidak nyaman karena bukti yang dikumpulkan tidak sesuai dengan harapan auditor internal akibat keterbatasan waktu.

\section{PENUTUP}

Penelitian ini bertujuan untuk menguji pengaruh pengalaman kerja, skeptisme profesional dan tekanan waktu terhadap pendeksi fraud. Responden yang digunakan dalam penelitian ini berjumlah 45 auditor yang bekerja di BPKP perwakilan Provinsi Jawa Tengah. Perhitungan dan pengujian diatas telah dilakukan menggukanan aplikasi SPSS Statistic 24, maka dapat disimpulkan bahwa pengalaman kerja dan skeptisme profesional menunjukan pengaruh positif terhadap pendeteksian fraud, tetapi untuk variabel tekanan waktu menunjukan pengaruh negatif terhadap pendeteksian fraud. Ketiga variabel independen diatas juga telah menunjukan pengaruh yang sangat signifikan terhadap variabel dependen pendeteksi fraud.

Keterbatasan pada penelitian ini ada pada ketiga variabel independen yang hanya menunjukan 30,9\% pengaruh terhadap variabel dependen, dimana masih terdapat $69,1 \%$ variabel lainnya yang dapat mempengaruhi pendeteksi fraud sebagai variabel dependen. Keterbatasan lainnya ada jumlah kuesioner, dimana jumlah kuesioner yang harusnya sejumlah 50 orang hanya menjadi 45 orang karena ada 3 kuesioner yang tidak diisi dengan lengkap dan 2 kuesioner tidak kembali, sehingga peneliti hanya menggunakan 45 kuesioner sebagai respondennya. Selanjutnya ada pada sampel, sampel penelitian ini hanya terbatas pada daerah Semarang, Jawa Tengah saja. Hasil dari penelitian ini memiliki kemungkinan akan menunjukan hasil yang berbeda, jika penelitian dilakukan dengan sampel yang lebih banyak dan wilayah yang lebih luas.

Saran bagi penelitian yang akan datang, disarankan agar memperluas wilayah objek yang digunakan atau bisa membandingkan antara satu wilayah dengan wilayah yang lainnya. Untuk variabel disarankan agar menambah atau mengganti dengan variabel lain yang belum ada di penelitian ini yang kiranya memberi pengaruh besar terhadap pendeteksi fraud misalnya independensi seorang auditor. Selanjutnya peneliti dapat menambahkan variabel moderasi atau interventing untuk memperoleh hasil yang berbeda dengan penelitian lain.

\section{DAFTAR PUSTAKA}

Albrecht, W. S., Albrecht, C. C., \& Albrecht, C. O. (2006). Fraud Examination (second edi).

Amrizal. (2004). Pencegahan dan Pendeteksian Kecurangan oleh Internal Auditor. Lestari Kiranatama.

$\begin{array}{ccr}\text { Anggriawan, E. F. }(2014) . & \begin{array}{r}\text { Pengaruh } \\ \text { Pengalaman }\end{array} \\ \text { Kerja, } & \text { Skeptisme } \\ \text { Profesional Dan Tekanan } & \text { Waktu } \\ \text { Terhadap Kemampuan Auditor } & \text { Dalam } \\ \text { Mendeteksi } & \text { Fraud (Studi Empiris Pada } \\ \text { Kantor Akuntan Publik Di Diy). Nominal, } & \text { Nom } \\ \text { Barometer Riset } & \text { Akuntansi } & \text { Dan } \\ \text { Manajemen, } & \text { 3, } & 2 . \\ \text { https://doi.org/10.21831/nominal.v3i2.26 } \\ 97\end{array}$


Arsendy, M. T., Anugerah, R., \& Diyanto, V. (2017). Pengaruh Pengalaman Audit, Skeptisme Profesional, Red Flags, dan Tekanan Anggaran Waktu terhadap Kemampuan Auditor dalam Mendeteksi Kecurangan (Studi Empiris pada Kantor Akuntan Publik di DKI Jakarta). Jurnal Online Mahasiswa Fakultas Ekonomi Universitas Riau, 4(1), 1096-1107.

Aulia, M. Y. (2013). Pengaruh Pengalaman, Independensi dan Skeptisme Profesional Auditor terhadap Pendeteksian Kecurangan. 2, 1-110.

Butar, S. G. A. B., \& Perdana, H. D. (2017). Penerapan Skeptisisme Profesional Auditor Internal Pemerintah dalam Mendeteksi Kecurangan (Studi Kasus pada Auditor Perwakilan BPKP Provinsi Jawa Tengah). Jurnal Ekonomi Dan Bisnis, 20(1), 169. https://doi.org/10.24914/jeb.v20i1.1003

Dandi, V., ' K., \& Safitri, D. (2017). Pengaruh Beban Kerja, Pelatihan dan Tekanan Waktu terhadap Kemampuan Auditor dalam Mendeteksi Kecurangan (Studi Empiris Bpk RI Perwakilan Provinsi Riau). Jurnal Online Mahasiswa Fakultas Ekonomi Universitas Riau, 4(1), 911-925.

Daraori. (2017). Jurnal Ilmiah Administrasi Publik ( JIAP ) Peran Auditor Internal Pemerintah Dalam Pencegahan Dan Pendeteksian Fraud. 3(4), 138-146.

Frederick, libby. (1990). EXPERIENCE AND THE ABILITY TO EXPLAIN AUDIT FINDINGS. Journal of Accounting Research, 28(2), 348-367.

Hafizhah, N., \& Abdurahim, A. (2019). Profesional, dan Pengalaman Kerja Terhadap Kemampuan Auditor Mendeteksi Kecurangan Pada Laporan Keuangan ( Studi pada Empiris Badan Pemeriksa Keuangan Perwakilan Provinsi Daerah Istimewa Yogyakarta ). 1(1), 68-77.

Hariyani, E., -, Z., \& Ramadhany, F. (2015). Pengaruh Pengalaman, Independensi, Skeptisme Profesional, Kompetensi, dan Komunikasi Interpersonal Auditor Kap terhadap Pendeteksian Kecurangan (Studi Empiris pada Kap di Wilayah Pekanbaru, Medan, dan Batam). Jurnal Online Mahasiswa Fakultas Ekonomi Universitas Riau, 2(2), 1-15.
Hilmi, F. (2011). Pengaruh Pengalaman, Pelatihan, dan Skeptisisme Profesional terhadap Pendeteksian Kecurangan.

Hiro Tugiman. (2019). Audit Internal Pengertian, Tujuan, Ruang Lingkup dan Tugas. 9 Juni.

Ida Ayu Indira Biksa1 I Dewa Nyoman Wiratmaja. (2017). PENGARUH PENGALAMAN, INDEPEDENSI, SKEPTISME PROFESIONAL AUDITOR PADA PENDETEKSIAN KECURANGAN. Jurnal Akuntansi Universitas Udayana, 17, 3. https://doi.org/10.1016/00323950(77)90421-X

Kartikasari, R. N., Irianto, G., \& Prihatiningtias, Y. W. (2017). Penerapan skeptisme profesional auditor internal pemerintah dalam mendeteksi kecurangan di Sektor Publik ( Studi pada Auditor di Perwakilan BPKP Provinsi Jawa Timur ). Jurnal Akuntansi Aktual, 4(2), 77-91.

Koroy, T. R. (2010). Pendeteksian Kecurangan (Fraud) Laporan Keuangan oleh Auditor Eksternal. Jurnal Akuntansi Dan Keuangan, 10(1), 22-23. https://doi.org/10.9744/jak.10.1.PP.2223

Kristina, M. D. dan T. U. (2018). Krisis Moneter yang Dialami Indonesia pada Tahun 1997-1998. 12 Mei.

Lestari, F. F. dan A. W. (2016). Eksistensi ‘ White Collar Crime' Di Indonesia: Kajian Kriminologi Menemukan Upaya Preventif. 6(1), 85-97.

Nasution, H. (2012). Pengaruh Beban Kerja, Pengalaman Audit dan Tipe Kepribadian Terhadap Skeptisme Profesional dan Kemampuan Auditor dalam Mendeteksi Kecurangan.

Nasution, H. (2014). Pengaruh Beban Kerja, Pengalaman Audit dan Tipe Kepribadian Terhadap Skeptisme Profesional dan Kemampuan Auditor dalam Mendeteksi Kecurangan. Journal Nominal, 3, 2.

Ningtyas, I., Delamat, H., \& Yuniartie, E. (2019). Pengaruh Pengalaman, Keahlian, Dan Skeptisisme Profesional Terhadap Pendeteksian Kecurangan (Studi Empiris Pada Bpk Ri Perwakilan 
Sumatera Selatan). AKUNTABILITAS: Jurnal Penelitian Dan Pengembangan Akuntansi, 12(2), 113-124. https://doi.org/10.29259/ja.v12i2.9312

Prasetyo, S., -, K., \& Hanif, R. (2015). Pengaruh Red Flags, Skeptisme Profesional Auditor, Kompetensi, Independensi, Dan Profesionalisme Terhadap Kemampuan Auditor Dalam Mendeteksi Kecurangan (Studi Empiris Pada Kantor Akuntan Publik Di Pekanbaru, Padang, Dan Medan Yang Terdaftar Di lapi 2013). Jurnal Online Mahasiswa Fakultas Ekonomi Universitas Riau, 2(1).

Purba, B. P. (2015). Fraud dan Korupsi Pencegahan Pencegahan, Pendeteksian, dan Pemberantasannya. Lestari Kiranatama.

Putra. (2017). Merugikan Keuangan Negara. 3 Maret. www.kompas.com

Putra, N. A. E. (2012). Pengaruh Kompetensi, Tekanan Waktu, Pengalaman Kerja, Etika dan Independensi Auditor Terhadap Pendeteksian fraud.

Putra, R. S., Andreas, \& Hardi. (2016). Pengaruh Keahlian Profesional, Kecermatan Profesional, Tekanan Anggaran Waktu Terhadap Pendeteksian Kecurangan Dengan Skeptisme Profesional Sebagai Variabel Moderasi (Studi Bpk Ri Perwakilan Provinsi Riau). 24(September), 124140.

Ranu, G. A. Y. N., \& Merawati, L. K. (2017). Kemampuan Mendeteksi Fraud Berdasarkan Skeptisme Profesional, Beban Kerja, Pengalaman Audit Dan Tipe Kepribadian Auditor. Jurnal Riset Akuntansi, 7(1), 79-90.

Rizki Inmas Pratiwi. (2017). Pengaruh Kompetensi, Independensi, Tekanan Anggaran Waktu dan Kompleksitas Tugas terhadap Kinerja Auditor Internal (Studi Empiris pada BPKP Perwakilan Sulawesi Barat).

Sahidin, I. (2018). PENGARUH KEAHLIAN FORENSIK, SKEPTISME PROFESIONAL DAN TEKANAN WAKTU TERHADAP PENDETEKSIAN KECURANGAN.
https://doi.org/10.1017/CBO9781107415 324.004

Simanjuntak, S., Hasan, A., \& Ali, A. A. (2015). Pengaruh Independensi, Kompetensi, Skeptisme Profesional Dan Profesionalisme Terhadap Kemampuan Mendeteksi Kecurangan (Fraud) Pada Auditor Di Bpk Ri Perwakilan Provinsi Sumatera Utara. Jurnal Online Mahasiswa Fakultas Ekonomi Universitas Riau, 2(2), 1-13.

Sofyan, A., -, A., \& Novita, U. (2015). Pengaruh Pengalaman, Beban Kerja, dan Pelatihan terhadap Skeptisme dan Kemampuan Auditor dalam Mendeteksi Kecurangan (Studi Empiris Pada Auditor di BPKP Perwakilan Provinsi Riau). Jurnal Online Mahasiswa Fakultas Ekonomi Universitas Riau, 2(1), 1-16.

Supriyanto. (2014). Pengaruh Beban Kerja, Pengalaman Audit, Tipe Kepribadian dan Skeptisme Profesional terhadap Kemampuan Auditor Dalam Mendeteksi Kecurangan.

Theodorus M. Tuanakotta. (2011). Berpikir Kritis dalam Auditing. Salemba Empat.

Trinanda, H. H. (2016). Pengaruh Skeptisme Profesional, Independensi dan Kompetensi terhadap Kemampuan Auditor Mendeteksi Kecurangan.

Umri, C., Islahuddin, \& Nadirsyah. (2015). Pengaruh Sikap Skeptisisme Profesional Auditor, Bukti Audit Kompeten Dan Tekanan Waktu Terhadap Pendeteksian Kecurangan. Jurnal Magister Akuntansi, 4(1), 20-28.

Utami, U., -, K., \& -, R. (2015). Pengaruh Integritas, Obyektivitas, Kerahasiaan, Kompetensi, dan Pengalaman Kerja terhadap Kinerja Auditor pada Inspektorat Provinsi Riau. Jurnal Online Mahasiswa Fakultas Ekonomi Universitas Riau, 2(2).

Www.bpkp.go.id. (2011). Polda Jateng Tangani 32 Kasus Korupsi Pejabat.

Yusrianti, H. (2015). Pengaruh Pengalaman Audit, Beban Kerja, Task Specific Knowledge Terhadap Pendeteksian Kecurangan. Jurnal Manajemen Dan Bisnis Sriwijaya, Vol.13(1), 55-72. 